\title{
PERSIAPAN PESERTA UJIAN MENGHADAPI UJI KOMPETENSI NASIONAL DIII KEBIDANAN
}

\author{
Rahmah Fitria \\ STIKes Panca Bhakti Bandar Lampung \\ e-mail: rahmahfitria89@gmail.com
}

\begin{abstract}
The objective of this study was to look at the phenomenon of participant's efforts in preparation for the National Diploma III Midwifery National competency test. The National Competency Test is an effort to measure the final result in the form of an outcome as a standard for measuring the knowledge, skills, and behavior of students in health institutions. This research used a qualitative design with a phenomenological approach. Data collection using the Snowball Sampling technique and collected using in-depth interviews conducted in a semi-structure. Data analysis refers to the constant comparative method and reliability is believed using triangulation. The results of the study revealed that all parties agreed with the policy of holding a national competency test but the participants opposed being carried out as an exit exam. The preparation that the exam participants did to face the Diploma III Midwifery National competency test used 3 methods, they were the private institution tutoring program, Self Directed Learning, and Institutional Guidance.
\end{abstract}

Keywords: National Competency Test; Midwife Competency Test; Midwifery Diploma; Exam Preparation.

\begin{abstract}
ABSTRAK
Penelitian bertujuan melihat fenomena upaya persiapan peserta mempersiapkan diri menghadapi uji kompetensi nasional DIII Kebidanan. Uji Kompetensi Nasional adalah suatu upaya pengukuran hasil akhir berupa outcome sebagai standar untuk mengukur pengetahuan, keterampilan dan perilaku peserta didik pada institusi bidang kesehatan. Desain penelitian adalah kualitatif dengan pendekatan fenomenologi. Pengumpulan data menggunakan teknik Snowball Sampling dan dikumpulkan dengan cara wawancara mendalam yang dilakukan secara semistruktur (Semistructure Interview). Analisis data mengacu pada constant comparative method dan kreabilitas diyakini dengan cara triangulasi. Hasil penelitian mengungkapkan bahwa semua pihak setuju dengan kebijakan diadakan uji kompetensi nasional tetapi peserta ujian menentang dilaksanakan sebagai exit exam. Persiapan yang peserta ujian lakukan untuk menghadapi uji kompetensi nasional DIII Kebidanan menggunakan Tiga metode yaitu mengikuti program lembaga swasta bimbingan belajar, Self Directed Learning dan Bimbingan Institusi.
\end{abstract}

Kata kunci: Uji Kompetensi Nasional, Ukom Bidan, DIII Kebidanan, Persiapan Peserta Ujian.

\section{PENDAHULUAN}

Pendidikan tinggi kesehatan memiliki tantangan internal dan eksternal (global) menghasilkan lulusan yang mampu memberikan pelayanan kesehatan bermutu dan mampu bersaing secara global dengan lulusan tenaga kesehatan di Negara lain. Relevansi kompetensi lulusan dengan kebutuhan masyarakat dan sistem kesehatan belum terpenuhi sehingga diperlukan peningkatan mutu pendidikan kebidanan dan mutu tenaga kesehatan. ${ }^{(1,2)}$

Pemerintah dengan dukungan dari organisasi profesi menerapkan beberapa upaya dalam menghadapi masalah dan tantangan tersebut yaitu salah satunya dengan sistem akreditasi untuk mejamin mutu pendidikan tinggi kesehatan sesuai standar pendidikan. Data akreditasi Program Studi Kebidanan per Februari 2012 oleh HPEQ adalah dari 728 institusi pendidikan bidan di Indonesia terdapat 454 institusi yang masih berlaku status akreditasinya, 259 institusi yang belum terakreditasi dan 15 institusi telah kadaluarsa status akreditasinya. ${ }^{(1,3)}$ Data akreditasi Program Studi Kebidanan yang terdaftar pada BAN-PT berjumlah 429 institusi pendidikan dan 9 diantaranya adalah Institusi Pendidikan D3 Kebidanan di Kota Padang. Dari 429 institusi pendidikan tersebut, 302 status akreditasi masih berlaku dan 127 sudah kadaluarsa dengan 3 institusi di antaranya adalah institusi pendidikan D3 Kebidanan di Kota Padang. ${ }^{(4)}$ Institusi Pendidikan kebidanan yang terdaftar pada LAMPTKes adalah sebanyak 246 Insititusi pendidikan. ${ }^{(5)}$ Data tersebut memperlihatkan bahwa sistem akreditasi saja belum mampu mengatasi masalah dan tantangan yang ada karena tidak semua institusi pendidikan bidan terdaftar dan terakreditasi sehingga diperlukan upaya lain untuk menjamin kualitas tenaga kesehatan sesuai standar kompetensi 
dan naskah akademik sistem pendidikan tiap profesi. Upaya lain tersebut adalah melalui uji kompetensi nasional. ${ }^{(6,7)}$ Berdasarkan data Ristedikti tahun 2018, hasil rerata tingkat kelulusan uji kopetensi nasional DIII Kebidanan adalah $55 \%$ dengan tingkat rerata terendah ada pada periode VIII tahun 2017 yaitu 22,89 $\%$ dan periode $\mathrm{X}$ tahun 2018 yaitu $27,95 \%$. $^{(8)}$

Fenomena dan data yang ada menunjukkan bahwa uji kompetensi nasional berperan penting untuk meningkatkan kualitas lulusan tenaga kesehatan. Keberhasilan suatu sistem dinilai dari unsur input, proses dan output/ outcome. Untuk mencapai output yang diinginkan, tentu diperlukan input dan proses yang baik. Salah satu input pada keberhasilan uji kompetensi nasional adalah kesiapan peserta ujian.

Penelitian ini bertujuan melihat bagaimana fenomena persiapan (input) uji kompetensi bidan yaitu fokus pada upaya persiapan peserta ujian dalam menghadapi uji kompetensi nasional DIII Kebidanan.

\section{METODE}

Jenis penelitian adalah kualitatif dengan pendekatan fenomenologi. Lokasi penelitian dilakukan di kota Padang dan Jakarta. Waktu penelitian mulai survey awal sampai penelitian yaitu bulan April 2016 - Agustus 2017.

Data diambil melaui informan terkait menggunakan teknik snowball sampling. Pemilihan informan pada penelitian kualitatif adalah hal yang krusial sehingga pemilihan informan dalam penelitian tidak diarahkan pada jumlah tetapi berdasarkan prinsip kesesuaian (appropriateness) dan kecukupan (adequacy). ${ }^{(9)}$

Pengumpulan data pada penelitian ini dilakukan dengan wawancara medalam yang dilakukan secara semistruktur (Semistructure Interview) yaitu salah satu jenis wawancara yang termasuk dalam kategori indeph interview. Data yang dikumpulkan dipaparkan dalam bentuk catatan lapangan. ${ }^{(10,11)}$ Validitas data penelitian dilakukan dengan empat kriteria meliputi kredibilitas, transferabilitas, dependabilitas dan konfirmabilitas. Proses analisis data yang dilakukan mengacu pada model perbandingan tetap (constant comparative method)..$^{(11)(12)}$

Penelitian ini telah mendapatkan persetujuan etik dari Komite Etika Penelitian Fakultas Kedokteran Unand No.067/KEP/FK/2016. Penelitian ini hanya dapat dilakukan triangulasi sumber karena keterbatasan waktu, izin dan kerahasiaan dokumen serta saat mengumpulkan data tidak ada pelaksanaan bimbingan belajar atau try out.

\section{HASIL}

\section{Temuan Umum}

Uji kompetensi Naional DIII Kebidanan di Indonesia dilakukan dengan tujuan untuk mendapatkan Surat Tanda Registrasi (STR) bidan yang dibutuhkan dalam mencari pekerjaan sebagai bukti bahwa lulusan bidan tersebut memiliki standar yang sesuai dengan standar kompetensi bidan yang sudah ditetapkan di Indonesia sehingga diharapkan dapat memberikan kualitas pelayanan yang baik yang dihasil akhirnya mampu membantu menurunkan jumlah Angka Kematian Ibu dan Angka Kematian Anak di Indonesia. Uji kompetensi bidan di Indonesia dilaksanakan dua kali dalam setahun. Pelaksanaan di awal tahun bagi retaker dan di akhir tahun bagi yang baru lulus pendidikan bidan.

\section{Kebijakan Uji Kompetensi Nasional DIII Kebidanan di Indonesia}

Tabel 1. Matriks Triangulasi Sumber tentang Tujuan Uji Kompetensi Nasional DIII Kebidanan

\begin{tabular}{|c|c|c|c|}
\hline $\begin{array}{c}\text { Pembuat } \\
\text { Kebijakan }\end{array}$ & Pelaksana & Peserta Ujian & $\begin{array}{c}\text { Analisis } \\
\text { triangulasi }\end{array}$ \\
\hline $\begin{array}{l}\text { Uji } \\
\text { Kompetensi } \\
\text { Kebidanan } \\
\text { bertujuan } \\
\text { menguji } \\
\text { standar } \\
\text { kompetensi } \\
\text { lulusan } \\
\text { kebidanan } \\
\text { dengan } \\
\text { melihat } \\
\text { kemampuan } \\
\text { kognitif dan } \\
\text { skilnya } \\
\text { sehingga } \\
\text { dihasilkan } \\
\text { lulusan } \\
\text { bidan yang } \\
\text { berkompete } \\
\text { n } \\
\text { memberikan } \\
\text { pelayanan } \\
\text { sesuai } \\
\text { profesinya }\end{array}$ & $\begin{array}{l}\text { Tujuan uji } \\
\text { kompetensi } \\
\text { bidan adalah } \\
\text { untuk } \\
\text { meninjau } \\
\text { kemampuan } \\
\text { lulusan } \\
\text { sehingga } \\
\text { tenaga } \\
\text { kesehatan } \\
\text { yang } \\
\text { dihasilkan } \\
\text { adalah tenaga } \\
\text { kesehatan } \\
\text { yang } \\
\text { berkompeten } \\
\text { dan untuk } \\
\text { meningkatka } \\
\text { n mutu } \\
\text { pendidikan } \\
\text { bidan di } \\
\text { Indonesia }\end{array}$ & $\begin{array}{l}\text { Uji } \\
\text { kompetensi } \\
\text { bidan karena } \\
\text { bertujuan } \\
\text { sebagai alat } \\
\text { uji } \\
\text { kompetensi } \\
\text { lulusan bidan } \\
\text { sehingga } \\
\text { dihasilkan } \\
\text { lulusan bidan } \\
\text { yang } \\
\text { berkompeten } \\
\text { dan } \\
\text { berkualitas } \\
\text { sesuai } \\
\text { kompetensiny } \\
\text { a }\end{array}$ & $\begin{array}{l}\text { Uji } \\
\text { kompetensi } \\
\text { penting } \\
\text { dilaksanakan } \\
\text { karena } \\
\text { tujuannya } \\
\text { adalah } \\
\text { sebagai alat } \\
\text { uji untuk } \\
\text { mengukur } \\
\text { dan meninjau } \\
\text { kompetensi } \\
\text { lulusan } \\
\text { sehingga } \\
\text { dihasilkan } \\
\text { lulusan bidan } \\
\text { yang } \\
\text { berkompeten } \\
\text { dan } \\
\text { berkualitas } \\
\text { dalam } \\
\text { memberikan } \\
\text { pelayanan } \\
\text { sesuai } \\
\text { profesinya } \\
\text { dan untuk } \\
\text { meningkatka } \\
\text { n mutu } \\
\text { pendidikan } \\
\text { bidan di } \\
\text { Indonesia }\end{array}$ \\
\hline
\end{tabular}

Tabel 2. Matriks Triangulasi Sumber tentang tujuan Uji Matriks Triangulasi Sumber tentang rencana Uji Kompetensi Nasional DIII Kebidanan sebagai Exit Exam 


\begin{tabular}{|c|c|c|c|}
\hline $\begin{array}{l}\text { Pembuat } \\
\text { Kebijakan }\end{array}$ & Pelaksana & $\begin{array}{c}\text { Peserta } \\
\text { Ujian }\end{array}$ & $\begin{array}{c}\text { Analisis } \\
\text { triangulasi }\end{array}$ \\
\hline $\begin{array}{l}\text { Pembuat } \\
\text { Kebijakan } \\
\text { dan Bagian } \\
\text { Monitoring } \\
\text { Evaluasi } \\
\text { uji } \\
\text { kompetensi } \\
\text { bidan } \\
\text { setuju } \\
\text { untuk } \\
\text { kedepanny } \\
\text { a diarahkan } \\
\text { uji } \\
\text { kompetensi } \\
\text { bidan } \\
\text { sebagai exit } \\
\text { exam }\end{array}$ & $\begin{array}{l}\text { Institusi } \\
\text { pendidikan } \\
\text { dan panitia } \\
\text { penyelenggar } \\
\text { a setuju bila } \\
\text { Uji } \\
\text { kompetensi } \\
\text { bidan di } \\
\text { Indonesia } \\
\text { dilakukan } \\
\text { sebagai exit } \\
\text { exam }\end{array}$ & $\begin{array}{l}\text { Calon } \\
\text { peserta tidak } \\
\text { setuju } \\
\text { dengan } \\
\text { rencana } \\
\text { diadakannya } \\
\text { uji } \\
\text { kompetensi } \\
\text { exam secara } \\
\text { exit exam } \\
\text { untuk } \\
\text { kedepannya } \\
\text { karena } \\
\text { dirasakan } \\
\text { tidak adil } \\
\text { sebagai } \\
\text { penentu } \\
\text { kelulusan } \\
\text { tanpa } \\
\text { melihat } \\
\text { pembelajara } \\
\text { n yang telah } \\
\text { ditempuh } \\
\text { selama } 3 \\
\text { tahun di } \\
\text { pendidikan } \\
\text { bidan }\end{array}$ & $\begin{array}{l}\text { Pembuat } \\
\text { Kebijakan, } \\
\text { bagian monev, } \\
\text { Institusi } \\
\text { pendidikan } \\
\text { setuju apabila } \\
\text { kedepannya uji } \\
\text { kompetensi } \\
\text { bidan } \\
\text { dilaksanakan } \\
\text { sebagai } \text { exit } \\
\text { exam namun } \\
\text { mahasiswa } \\
\text { bidan kurang } \\
\text { setuju karena } \\
\text { menganggap } \\
\text { uji kompetensi } \\
\text { saja kurang } \\
\text { adil untuk } \\
\text { menentukan } \\
\text { kelulusan } \\
\text { mereka yang } \\
\text { telah } \\
\text { menempuh } \\
\text { pendidikan } \\
\text { bidan selama } \\
\text { tiga tahun. } \\
\text { Mahasiswa } \\
\text { berpendapat } \\
\text { kelulusan tidak } \\
\text { hanya diukur } \\
\text { dari uji tulis } \\
\text { sekali waktu } \\
\text { tapi sebaiknya } \\
\text { memperhatika } \\
\text { n evaluasi } \\
\text { belajar yang } \\
\text { telah } \\
\text { dilaksanakan } \\
\text { selama tiga } \\
\text { tahun } \\
\text { pendikan. Uji } \\
\text { kompetensi } \\
\text { bidan } \\
\text { sebaiknya } \\
\text { diikuti dengan } \\
\text { OSCE untuk } \\
\text { menguji } \\
\text { kemamampuan } \\
\text { skill nya. }\end{array}$ \\
\hline
\end{tabular}

Persiapan Peserta Ujian menghadapi Uji Kompetensi Nasional DIII Kebidanan di Indonesia

Tabel 3. Matriks Triangulasi Sumber tentang Persiapan Peserta Ujian menghadapi Uji Kompetensi Nasional DIII Kebidanan

\begin{tabular}{llll}
\hline $\begin{array}{c}\text { Pembuat } \\
\text { Kebijakan }\end{array}$ & Pelaksana & $\begin{array}{c}\text { Peserta } \\
\text { Ujian }\end{array}$ & $\begin{array}{c}\text { Analisis } \\
\text { triangulasi }\end{array}$ \\
\hline Melakukan & Tiga dari & Rerata & Persiapan \\
uji validasi & Empat & peserta ujian & calon peserta \\
soal dengan & Institusi & mengatakan & menghadapi \\
mengadakan & Pendidikan & sudah siap & ujian adalah \\
Try Out & DIII & lebih dari 50 & mengikuti \\
Nasional & Kebidanan di & \% dalam & bimbingan \\
yang & Kota Padang & menghadapi & belajar, \\
\hline
\end{tabular}

\begin{tabular}{|c|c|c|c|}
\hline $\begin{array}{l}\text { diadakan } \\
\text { oleh } \\
\text { AIPKIND }\end{array}$ & $\begin{array}{l}\text { mengadakan } \\
\text { dan } \\
\text { mewajibkan } \\
\text { peserta ujian } \\
\text { untuk } \\
\text { mengikuti Try } \\
\text { Out yang } \\
\text { diadakan } \\
\text { AIPKIND dan } \\
\text { yang diadakan } \\
\text { oleh Institusi } \\
\text { sendiri } \\
\text { sehingga } \\
\text { peserta ujian } \\
\text { mendapatkan } \\
\text { minimal } 2 \text { kali } \\
\text { latihan ujian } \\
\text { melalui try } \\
\text { out. } \\
\text { Satu Institusi } \\
\text { membebaskan } \\
\text { mahasiswanya } \\
\text { untuk tidak } \\
\text { ikut try out } \\
\text { baik Nasional } \\
\text { maupun try } \\
\text { out Institusi. } \\
\text { Empat } \\
\text { Institusi } \\
\text { Pendidikan } \\
\text { DIII } \\
\text { Kebidanan di } \\
\text { Kota Padang } \\
\text { telah } \\
\text { mengenalkan } \\
\text { bentuk soal } \\
\text { ukom minimal } \\
\text { mulai dari } \\
\text { semester II } \\
\text { yaitu ketika } \\
\text { memasuki } \\
\text { mata kuliah } \\
\text { Asuhan } \\
\text { Kebidanan } \\
\text { Kehamilan }\end{array}$ & $\begin{array}{l}\text { Uji } \\
\text { Kompetensi } \\
\text { Nasional } \\
\text { DIII } \\
\text { Kebidanan. } \\
\text { Persiapan } \\
\text { yang peserta } \\
\text { ujian } \\
\text { lakukan ada } \\
3 \text { teknik, } \\
\text { yaitu: } \\
\text { 1. Program } \\
\text { Bimbingan } \\
\text { Belajar } \\
\text { peserta ujian } \\
\text { mengikuti } \\
\text { lembaga } \\
\text { bimbingan } \\
\text { belajar baik } \\
\text { online } \\
\text { maupun } \\
\text { offline } \\
\text { 2. Self } \\
\text { Directed } \\
\text { Learning } \\
\text { peserta ujian } \\
\text { belajar } \\
\text { secara } \\
\text { mandiri } \\
\text { dengan cara } \\
\text { latihan- } \\
\text { latihan soal } \\
\text { yang } \\
\text { didapatkan } \\
\text { dari } \\
\text { berbagai } \\
\text { sumber } \\
\text { (online, } \\
\text { buku, } \\
\text { catatan) } \\
3 . \\
\text { Bimbingan } \\
\text { Institusi } \\
\text { peserta ujian } \\
\text { mengatakan } \\
\text { ada } \\
\text { bimbingan } \\
\text { langsung } \\
\text { dari institusi } \\
\text { pendidikan, } \\
\text { mengikuti } \\
\text { try out dan } \\
\text { sudah } \\
\text { dikenalkan } \\
\text { bentuk soal } \\
\text { ukom sejak } \\
\text { semester } \\
\text { awal } \\
\text { a }\end{array}$ & $\begin{array}{l}\text { mengakses } \\
\text { contoh soal } \\
\text { dari berbagai } \\
\text { sumber } \\
\text { internet, } \\
\text { bimbingan } \\
\text { dari institusi, } \\
\text { pengenalan } \\
\text { bentuk soal } \\
\text { dari awal } \\
\text { perkuliahan, } \\
\text { latihan soal } \\
\text { dari buku } \\
\text { dan catatan } \\
\text { kakak } \\
\text { tingkat serta } \\
\text { mengikuti } \\
\text { try out } \\
\text { institusi dan } \\
\text { AIPKIND }\end{array}$ \\
\hline
\end{tabular}

\section{PEMBAHASAN}

\section{Kebijakan}

Hasil temuan penelitian menunjukkan bahwa ketiga sumber setuju bahwa kebijakan uji kompetensi nasional DIII Kebidanan mempunyai tujuan yang baik. Ketiga sumber yaitu pembuat kebijakan (Kementerian Ristedikti, MTKI, Organisasi Profesi dan AIPKIND), pelaksana (Panitia Penyelenggara, Institusi Pendidikan, Organisasi Profesi) dan peserta ujian sependapat bahwa Uji Kompetensi Nasional penting dilaksanakan karena tujuannya adalah sebagai alat uji 
untuk mengukur dan meninjau kompetensi lulusan sehingga dihasilkan lulusan bidan yang berkompeten dan berkualitas dalam memberikan pelayanan sesuai profesinya dan untuk meningkatkan mutu pendidikan bidan di Indonesia.

Tujuan dilaksanakan uji kompetensi bidan adalah persiapan menghadapi tantangan global melalui standarisasi registrasi dan izin praktik bidan yang akan memberikan pelayanan kesehatan di Indonesia dan mendorong perbaikan kurikulum dan proses pembelajaran institusi kebidanan di Indonesia yang akan menjadi dasar untuk pembinaan mutu pendidikan kesehatan oleh kementerian. ${ }^{(13)}$ Tujuan pelaksanaan uji kompetensi dalam bidang pendidikan adalah mendorong perbaikan kurikulum dan proses pemberlajaran di tiap institusi dan menjadi dasar pembinaan mutu pendidikan bidang kesehatan yang menjadi tanggung jawab Kementerian. Hasil uji kompetensi juga akan menjadi dasar pembinaan program studi bidang kesehatan, dan menentukan kuota penerimaan mahasiswa baru program studi tersebut. ${ }^{(13)}$

Berbeda dengan temuan penelitian tentang Tujuan Kebijakan, pada hasil temuan tentang rencana uji kompetensi nasional DIII Kebidanan sebagai exit exam tidak mendapatkan kesepakatan bersama. Pembuat Kebijakan dan Pelaksana setuju walaupun pada pelaksanaannya memerlukan persiapan dan evaluasi lebih lanjut. Peserta ujian menentang rencana tersebut karena dianggap tidak adil. Tidak adil disini diungkapkan karena satu kali pelaksanaan ujian tulis dirasa tidak dapat mengukur dan mengevaluasi usaha dan hasil pendidikan yang telah mereka tempuh selama minimal tiga tahun.

\section{Persiapan Peserta Ujian}

Hasil temuan penelitian mengungkapkan peserta ujian sudah mempersiapkan diri untuk menghadapi uji kompetensi nasional dengan kesiapan lebih dari $50 \%$. Persiapan yang peserta ujian lakukan untuk menghadapi uji kompetensi nasional DIII Kebidanan menggunakan 3 metode yaitu mengikuti program lembaga swasta bimbingan belajar, Self Directed Learning, dan mengikuti bimbingan khusus yang diadakan di institusi pendidikan masing-masing.

Tiga Metode persiapan peserta ujian:

1. Mengikuti Program Lembaga Swasta Bimbingan Belajar

Peserta ujian mengikuti lembaga bimbingan belajar khusus yang menawarkan layanan bimbingan belajar menghadapi uji kompetensi nasional. Bimbingan belajar ini berupa online yaitu dari web tertentu maupun offline yaitu peserta ujian datang langsung ke alamat lembaga tersebut. Bimbingan dilakukan dua kali dalam seminggu.

\section{Self Directed Learning (Belajar Mandiri)}

Peserta ujian belajar secara mandiri dengan cara melatih mengerjakan bentuk soal ukom. Soal-soal tersebut didapatkan peserta ujian dari berbagai sumber. Sumber yang paling utama adalah internet. Sumber lainnya adalah buku, warisan kumpulan soal dari kakak tingkat, aplikasi telepon genggam dan aplikasi flashdisk khusus dari penerbit buku $\mathrm{x}$.

\section{Bimbingan Institusi}

Peserta ujian mengikuti bimbingan langsung dari institusi pendidikan,. Bimbingan ini diberikan sebulan sebelum hari ujian. Institusi juga mengadakan latihan ujian melalui pengadaan Try Out minimal dua kali yaitu Try Out Nasional yang diadakan oleh AIPKIND dan Try Out Internal yang diadakan oleh Institusi Pendidikan. Bimbingan Institusi pendidikan lainnya yang diberikan ke peserta didik adalah peserta didik sudah dikenalkan bentuk soal ukom sejak dini yaitu sejak semester II atau ketika peserta didik mempelajari mata kuliah Asuhan Kebidanan Kehamilan.

Metode lainnya yang dilakukan peserta ujian adalah melakukan diskusi antar sesama peserta ujian saat melatih menjawab soal.

Dari paparan hasil penelitian juga dikemukakan bahwa bentuk persiapan bagi calon peserta ujian yang difasilitasi oleh institusi pendidikan kebidanan dan AIPKIND adalah melalui pelaksanaan try out uji kompetensi. Hasil temuan memperlihatkan diantara lima informan yang berasal dari empat institusi pendidikan yang berbeda, satu diantaranya mengatakan tidak mewajibkan mahasiswanya untuk mengikuti try out uji kompetensi bidan dikarenakan ketidaksesuaian waktu yaitu mahasiswa sedang praktek dilapangan sehingga mengalami kesulitan untuk izin libur dari pihak lapangan untuk mengikuti try out sehingga Institusi menyerahkan kembali keikutsertaan kepada mahasiswa. Hal ini menyebabkan jumlah mahasiswa yang mengikuti try out sedikit. Data persentase tingkat ketidaklulusan di Institusi tersebut cenderung tinggi.

Berikut adalah data persentase tingkat ketidaklulusan mahasiswa Institusi tersebut berturut turut periode IV/2015, V/2016, VI/2016, VII/2017. VIII/2017, XI/2018 adalah 24,51\%, 50,43\%, 71,19\%, $70 \%, 100 \%, 92,3 \%$ dan 66,6\%. Bila data tersebut dihubungkan dengan ketidakikutsertaan peserta pada try out maka terlihat try out merupakan salah satu faktor penting pada persiapan menghadapi uji kompetensi bidan. ${ }^{(8)}$

Try out diadakan sebanyak dua kali setiap tahun yaitu oleh institusi dan secara nasional oleh AIPKIND. 
Try Out ini dilaksanakan agar peserta ujian Uji Kompetensi Nasional dapat lebih siap dan percaya diri dalam menghadapi ujian yang sesungguhnya dan melihat serta melatih bentuk gambaran soal yang akan muncul pada saat uji kompetensi bidan sesungguhnya. Ibu Riyanti Wikaningrum selaku ketua LPUK-Nakes sekretaris AIPKI pada paparan materi seminar Nasional dan Lokakarya Uji Kompetensi Tenaga Kesehatan yang dilaksanakan di Universitas Padjadjaran menjelaskan bahwa salah satu Lesson Learnt dari proses persiapan adalah Uji coba (Try Out) yang bertujuan sebagai media sosialisasi, uji coba metode, sistem uji dan materi uji validitas soal uji kompetensi bidan. ${ }^{(14)}$

Mengikuti bimbingan belajar, try out dan Self Directed Learning adalah cara-cara dimana peserta ujian berupaya melatih diri untuk terbiasa mengerjakan soal-soal ujian secara terus menerus dengan tujuan membiasakan diri untuk kenal dengan pola soal ujian. Cara ini dinamakan teknik mengulang. Teknik mengulang adalah teknik paling efektif dalam melekatkan informasi ke otak kita. (15, 16) Hasil Penelitian tahun 2019 menunjukkan ada hubungan positif antara kemampuan Self Directed Learning dan pencapaian hasil belajar. ${ }^{(17)}$

Hasil temuan penelitian juga memperlihatkan bahwa Institusi telah mengenalkan bentuk soal-soal uji kompetensi bidan kepada mahasiswa sejak awal semester yang diperkuat memasuki semester lima. Institusi telah mengenalkan bentuk soal vignette melalui ujian akhir semester. Walaupun institusi sudah mengaku mengenalkan soal dari awal tetapi tidak jelas terungkapkan apakah mahasiswa sudah dikenalkan blueprint dari soal-soal tersebut. Proses uji tidak hanya dapat dilihat secara tiba-tiba tetapi secara bertahap karena sistem uji ini bersifat drive learning yang artinya adalah mahasiswa diuji bertahap contohnya ujian akhir semester atau program atau quiz- quiz sehingga hal tersebut dapat menjadi alat uji bagi Institusi pendidikan untuk memantau sejauh mana kemampuan mahasiswa sebelum mereka melaksanakan uji kompetensi.

\section{KESIMPULAN}

Kebijakan pelaksanaan Uji Kompetensi Nasional DIII Kebidanan sudah diatur dalam Peraturan Menteri Riset, Teknologi, dan Pendidikan Tinggi No 12 Tahun 2016 dan SK Menteri No 307/M/Kp/IV/2015. ${ }^{(18,19)}$

Semua pihak terkait (pembuat kebijakan, pelaksana dan peserta) setuju dengan dilaksanakannya kebijakan tersebut untuk mencapai tujuan peningkatan kualitas lulusan kebidanan namun rencana pelaksanaan kearah exit exam ditentang oleh Peserta Ujian.

Persiapan yang peserta ujian lakukan untuk menghadapi uji kompetensi nasional DIII Kebidanan menggunakan 3 metode yaitu Program Lembaga Swasta Bimbingan Belajar, Self Directed Learning dan Bimbingan Institusi.

\section{UCAPAN TERIMA KASIH}

Penulis mengucapkan terima kasih kepada Kasubdit kompetensi lulusan di direktorat penjaminan Mutu Kementerian Riset, Teknologi, dan Pendidikan Tinggi Republik Indonesia, kepala Pusat Pendidikan Sumber Daya Manusia Kesehatan dan para staf, Ketua Divisi Uji Kompetensi MTKI, AIPKIND Padang, IBI Provinsi Sumatera Barat dan IBI Kota Padang yang telah memberikan izin, fasilitas dan kemudahan dalam penelitian ini

\section{DAFTAR PUSTAKA}

1. Anderson I MA, Marzoeki P, Pambudi E. Distribution and Performance of Physicians, Nurses and Midwives in Indonesia: an update. 2014:1-2.

2. BPPSDMK. Peran Institusi Pendidikan dalam Meningkatkan Kualitas Lulusan yang Kompeten melalui Uji Kompetensi. . Pusat Standarisasi, Sertifikasi dan Pendidikan Berkelanjutan SDM Kesehatan; 2014. p. 5-6.

3. HPEQ. Implementation Completion and Results Report on a Loan to the Republic of Indonesia for a Health Professional Education Quality Project (HPEQ)2015.

4. Status Akreditasi Pendidikan Kebidanan di Kota Padang [Internet]. 2016 [cited November 2016]. Available from: http://banpt.kemdiknas.go.id/hasil-pencarian.php.

5. Status Akreditasi [Internet]. 2016 [cited November 2016]. Available from: http://banpt.kemdiknas.go.id/hasil-pencarian.php.

6. Direktori Pencarian Prodi [Internet]. 2018 [cited July 2018]. Available from: https://banpt.or.id/direktori/prodi/pencarian_pr odi.

7. Akreditasi Institusi Pendidikan Kebidanan di Indonesia [Internet]. 2018 [cited July 2018]. Available from: http://lamptkes.org/akreditasi/pencarian/all.

8. Data Statistis Tingkat Kelulusan Uji Kompetensi Bidan [Internet]. Kementerian Riset Teknologi dan Pendidikan Tinggi (Kemenristedikti). 2018 [cited July 2018]. Available from: http://ukbidan.ristekdikti.go.id/pages/statistik_1 ulus.

9. EK P. Pendekatan Kualitatif untuk Perilaku Manusia. 3, editor2007. 
10. Satori DdK, A. Metodelogi Penelitian Kualitatif. Bandung: Alfabeta; 2014.

11. Sugiyono. Metode penelitian Manajemen. Bandung: Alfabeta; 2014.

12. Emzir. Metodologi Penelitian Pendidikan Kuantitatif dan Kualitatif. Jakarta: Rajawali Press; 2011.

13. Kemenristedikti. Implementasi Uji Kompetensi Nasional bidang Kesehatan sebagai Langkah Konkrit Penjaminan Mutu Pendidikan Tinggi Kesehatan2016 July 2018]. Available from: https://ristekdikti.go.id/implementasi-ujikompetensi-nasional-bidang-kesehatansebagai-langkah-konkrit-penjaminan-mutupendidikan-tinggi-kesehatan/.

14. Riyanti. Seminar Nasional dan Lokakarya Uji Kompetensi Tenaga Kesehatan. Bandung: Universitas Padjadjaran; 2017.

15. Augustin M. How to Learn Effectively in Medical School: Test Yourself, Learn Actively, and Repeat in Intervals. Yale J Biol Med. 2014;87(2):207-12.

16. Tony. Buku Pintar Mind Map Untuk Anak. Jakarta: Gramedia Pustaka Utama; 2014.

17. Muhamad Isnaini ABAP, Fanny Dewi Sartika, Fitrawati Arifuddin, . KEMAMPUAN SELF DIRECTED LEARNING DAN PENCAPAIAN HASIL BELAJAR: Studi Cross Sectional Journal of Islamic Nursing. 2019;4:68-76.

18. Undang- Undang No. 12 Tahun 2012 tentang Pendidikan Tinggi, (2012).

19. Keputusan Menteri Riset, Teknologi dan Pendidikan Tinggi Republik Indonesia Nomor 307/M/Kp/IV/2015 tentang Satuan Biaya Penyelenggaraan Uji Kompetensi Nasional Program Diploma III Kebidanan, Program Diploma III Keperawatan dan Program Profesi NERS Tahun 2015, (2015). 